\title{
Ultraviolet-induced fluorescence of lubricate oils
}

The paper describes the study on relationship between the engine lubricate oil quality and fluorescence phenomenon. In order to determination the Excitation-Emission spectra (EEMs) of oil samples, spectrofluorometer combined with the optical fiber system were applied. Two methods of fluorescence measurement, respectively: when oil diluted in non-fluorescent solvent (n-hexane) is placed in the quartz-cuvette inside the spectrofluoromether, and when oil sample is placed outside the spectrofluoromerher (then EEMs is measured through the optical fiber sensor) were applied to analysis the shape of EEMs of lubricate oil. Moreover in the second case of measurement, the optical fiber sensor was placed for the angle of 45 degrees to the oil surface, respectively, above the oil surface and beneath the oil surface, directly in oil. Preliminary scientific results presented in this paper - on the one hand - indicate diversity in the shape of EEMs depending on the method of fluorescence measurement, on the other hand-indicate possibility to measure fluorescence of oil directly in engine lubricate oil circuit.

Key words: lubricate oil, fluorescence, optical fiber

\section{Fluorescencja oleju smarnego indukowana światłem ultrafioletowym}

$W$ artykule przedstawione sa wyniki badań dotyczace zwiazku pomiędzy jakościa oleju smarnego a zjawiskiem fluorescencji. W celu wyznaczenia widm zupelnych fluorescencji próbek oleju wykorzystano spektrofluorymetr połaczony ze świattowodowym systemem pomiarowym. Analizowany jest kształt widm odnoszacych się do oleju smarnego $w$ dwóch przypadkach, odpowiednio, gdy: olej jest rozpuszczony $w$ niefluoryzującym medium (n-hexan) $i$ umieszczony jest $w$ przyrzadzie $w$ kwarcowej kuwecie oraz $w$ przypadku kiedy próbka oleju znajduje się na zewnątrz przyrządu,sygnał jest przenoszony światłowodem. Ponadto $w$ przypadku pomiarów z zastosowaniem świattowodu ustawiona pod kątem 45 o głowica pomiarowa zestawu świattowodowego znajduje się, odpowiednio: $w$ powietrzu nad powierzchnia oleju albo pod powierzchnię oleju. Przedstawione $w$ niniejszym artykule wstępne wyniki badań, z jednej strony wskazuja na zróżnicowanie ksztaltów widm zupetnych fluorescencji względem metody pomiarowej, z drugiej strony - wskazują na możliwość wyznaczania fluorescencji bez wstępnej obróbki laboratoryjnej, bezpośrednio w silnikowym obiegu oleju smarnego.

Słowa kluczowe: olej smarny, fluorescencja, sensor optyczny

\section{Introduction}

In the history of the development of internal combustion engines lubricating oils play an important role. In the past various physical and chemical indicators of lubricate oil usefulness have been introduced. In general, temperature dependence of viscosity is in use as the essential parameter for oil characterisation. To other significant parameters belongs water content, total acid number, total base number, rheometric or tribometric characteristics $[6,9]$. Every alteration of measurable in oil values contain information about the changes of exploitive quality of the lubricate oil.

Polycyclic hydrocarbons found in refinery products have ability to absorb ultraviolet (UV) radiation, in order to further emit light which interact with numerous components of petroleum and finally may came out of the sample to hit the photodetector of spectrofluorometer. Due to this reason changes in composition of petroleum products affect composition of light emitted from UV excited oil. Moreover, spectral composition of emitted light depends also on a spectrum of illuminating (exciting) light. Spectrofluorymetry in relation to the crude oil refinery products have been applied yet, for example Markova et al. [4] tested fluorescence sensor for characterization hydraulic oil deterioration, Omrani et al. [7] analyzed oxidative stability of lubricant oil measuring fluorescence excitationemission spectra. Moreover, Stelmaszewski [8] evidenced that individual types of refinery products are characterized by different fluorescence spectra. Furthermore, optical fiber spectroscopy with applying chosen wavelengths for measuring quality indicators of lubricant oils were carried out by Mignani et al. [5]. Our experience in this subject concerns the study of oil-in-water emulsions [3], and recently we started to study fluorescence of used lubricating oil $[1,2]$ - differences for fresh and used oil have 
been shown. Taking into account above mentioned it is worth checking out the relationship between variations in the fluorescence of oil and the quality of oil working in engine system.

In this paper we present results of introductory tests basing on so-called excitation-emission spectra (EEMs) of lubricate oil in various geometry of measurement, namely:

/1/ directly in oil, where oil sample is placed outside the spectrofluorometer (then EEMs is observed through optical fiber sensor),

/2/ oil diluted in non-fluorescent solvent is placed in a quartz cuvette (classical measurement based on spectrofluoromer is performed).

Discussion on lubricate oil fluorescence spectra for both methods of measurement is further continued.

\section{Material and method}

\subsection{Material}

Lubricate oil Titan Truck Plus 15W40 (TTP 15W40) were sampled from engine lubricate circuit after 178 hours of exploitation in the ship engine 3AL 25/30 Cegielski-Sulzer with the power 396 $\mathrm{kW}$ [1]. A part of oil sample was diluted in $\mathrm{n}$ hexane with $96 \%$ purity and oil samples in nhexane with oil concentration $100 \mathrm{mg} / \mathrm{kg}$ were prepared. Oil used in engine circuit visually differs from fresh one (is darker) which is shown in Fig. 1. Moreover, in Fig. 1 the ability to fluorescence of those two forms of oils is illustrated - oil which was sampled from engine lubricate circuit fluoresces less than fresh one. In this study to detailed spectral measurement were destined partly used oil obtained from the engine.

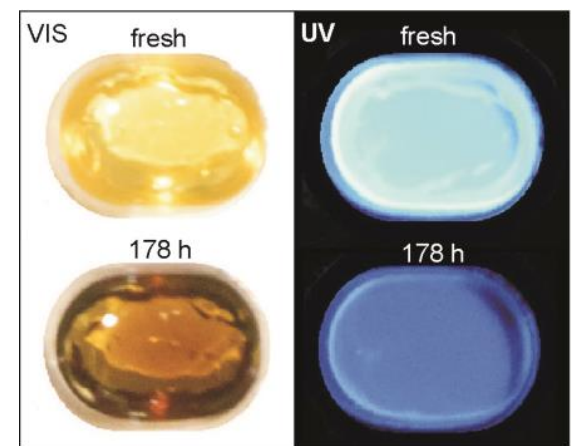

Fig. 1. Lubricate oil Titan Truck Plus 15 W40 fresh (upper) and used (lower) illuminated by filament lamp (left) and by ultraviolet lamp (right).

\subsection{Method}

To measure excitation-emission spectra (EEMs) of oil samples two different methods of samples excitation and registration of emission of light were applied, namely:

- by classical method, i.e. directly in spectrofluorometer (oil hexane-dilution in quartz cuvette)
- outside the spectrofluorometer using optical fiber system (Fig. 2).

EEMs for the $n$-hexane solvent and pure oil samples were measured in $1 \times 1 \mathrm{~cm}$ quartz cuvette. The following measurement parameters were applied: excitation wavelength from $200 \mathrm{~nm}$ to 340 $\mathrm{nm}$ with excitation sampling interval $5 \mathrm{~nm}$, emission wavelength from $260 \mathrm{~nm}$ to $450 \mathrm{~nm}$ with emission sampling interval $5 \mathrm{~nm}$, excitation slit $5 \mathrm{~nm}$, emission slit $5 \mathrm{~nm}$, integration time $0.5 \mathrm{~s}$ and photomultiplier tube voltage $400 \mathrm{~V}$ [1,2].

Next excitation-emission spectra of four oil samples for TTP $15 \mathrm{~W} 40$ were measured using optical fiber set (Fig. 1) manufactured by Lumex Ltd. St. Petersburg. This device consists of $2 \times 30$ fiberglasses of diameter $0.1 \mathrm{~mm}$ everyone (30 fiberglasses transmit light exciting fluorescence, other 30 ones transmit light emitted by oil). Oil samples were excited above the surface of oil and beneath the surface of oil for the distance of oil surface $2 \mathrm{~mm}$. The measurement were performed under 45 o to oil surface (Fig. 3).

EEM spectra for $n$-hexane solvent at a stabilised temperature $20^{\circ} \mathrm{C}$ for two types of EEMs measurement, were performed. Next, EEM spectra of four oils samples were measured, also at a stabilised temperature $20^{\circ} \mathrm{C}$.

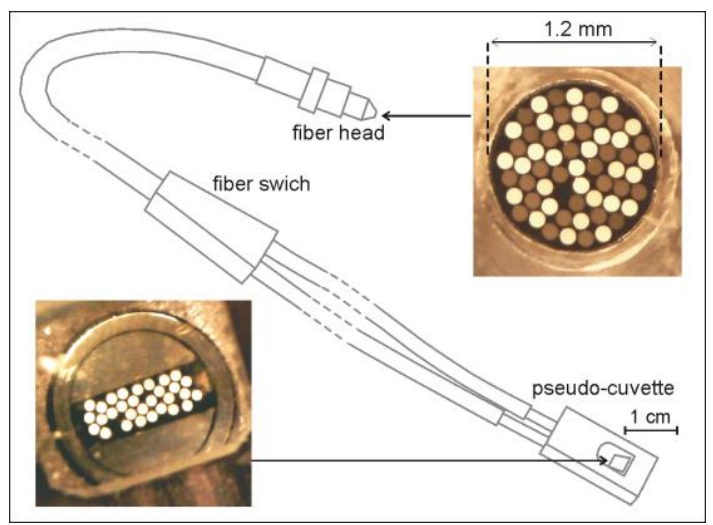

Fig. 2. Optical fiber system.

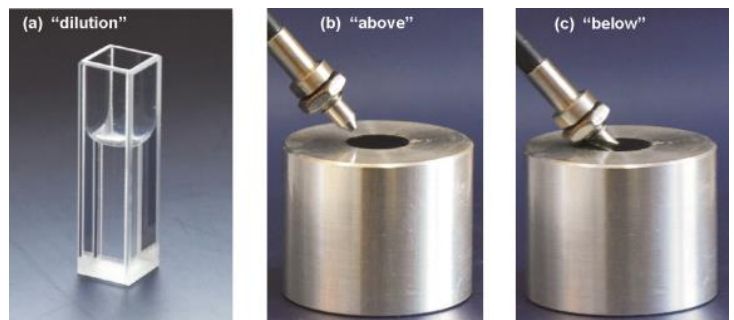

Fig. 3. Three ways to determine the EEM spectra: hexane solution of oil (a), directly in oil - above the surface (b), directly in oil - beneath the surface (c)

The EEMs is registered in numeric form as a table consisting of 3111 numbers (51 excitation wavelengths, 61 emission one). Results when emission wavelength are equal or less than excitation are blind (due to energy of emitted photon are less than 
energy of excitation photon - which is an essence of fluorescence phenomenon).

\section{Results and discussion}

As was above mentioned measurements of EEM spectra were carried out in three methods (visualized in Fig. 3). Results - fluorescence as the function of two variables (excitation wavelength and emission wavelength) are visualized as normalized 3D graphs in the Fig. 4 and as map visualization in the Fig. 5. The shapes of those three spectra differ from each other significantly. Oil diluted in nofluorescent solvent (n-hexane) indicates fluorescence spectrum in short wave region $(200-300 \mathrm{~nm})$, whereas fluorescence induced directly in oil is placed in longer wavelengths. Immersion of the

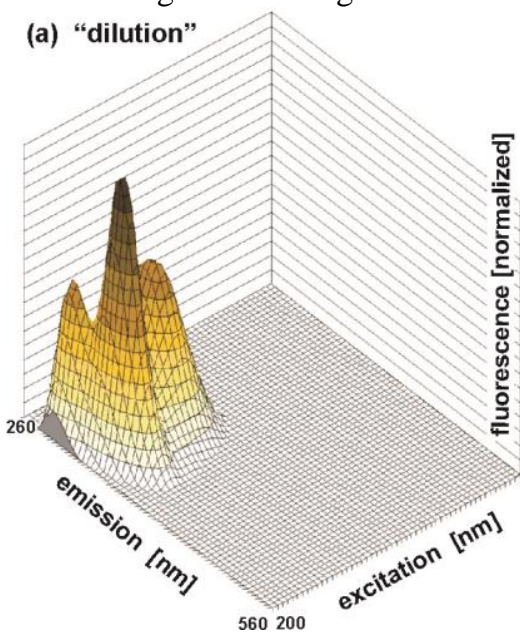

(b) "above"

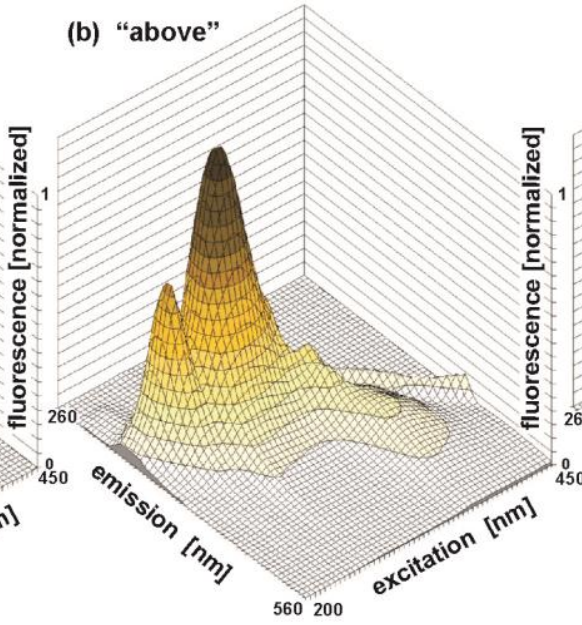

Fig. 4. Excitation-Emission spectra (EEMs) of used lubricate oil (178 h in engine circuit) measured in three fiber-head in the oil changes radically the shape of EEMs (extremes are shifted toward long wavelengths). The process of the light beam forming which going through the monochromator into photomultiplier (detector) of spectrophotometer in every case is different. The photons emitted by fluorescent centers have low chance to reach detector without repeated absorption and secondary absorption is in many cases connected with reemission. Such process can be repeated many times, especially in condensed form of analyzed substance (no-diluted oil). In this way forms the final spectrum of light which reaching the detector and is registered as two-dimensional numeric table.

\section{Fig. 4. Excitation-Emission spectra (EEMs) of used lubricate oil (178
methods (explained in Fig. 3)}
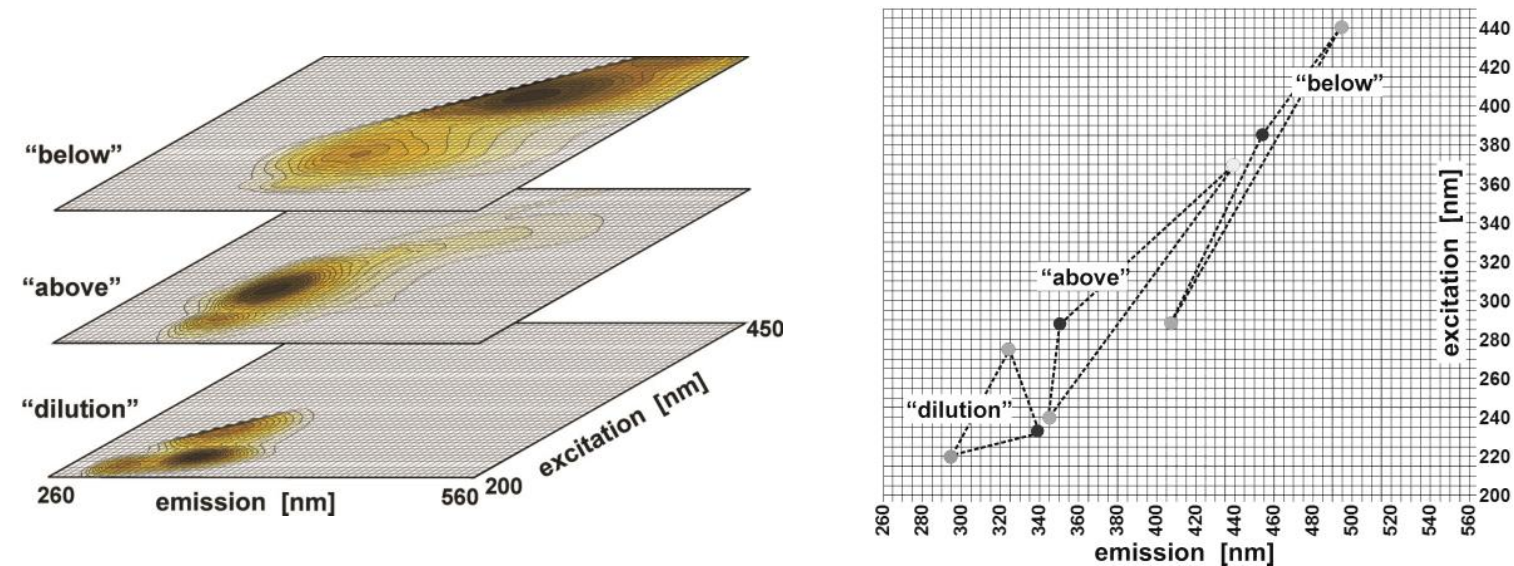

Fig. 5. Regions of oil fluorescence as the dependence on the measuring method (left) and positions of main peaks in relation to studied methods (right)

It can be assumed that in relation to the practice not necessarily measurement of the whole EEMs (like in this study) must be performed. Presumably the detector of fluorescence may be simplified to possibility of measurement in a limited number of wavelengths of both an excitation and an emission light. To this end, further research would be needed.

At the current stage of research the categorical declaration which above method should be preferred is impossible. Presented results show indeed well developed fluorescence spectra of lubricate oil 
independently on implemented and above described method, but there is not known in which method process of deterioration of oil during its working in

\section{Conclusions}

Fluorescence centers that are part of chemical compounds of lubricate oil deliver a possibility to implement fluorescence techniques for spectral characterization of those refinery products directly in those studied medium using optical fiber system connecting spectrofluorometer with the point where the oil is placed. The head of optical fiber sensor can be positioned above the oil surface or can be immersed into oil. It turned out that the shape of fluorescence spectrum depends on measure circumstances. Relatively well developed spectrum is observed when the head of optical fiber sensor is immersed. Obtained results allow to suggest that fluorescence may be linked to the degree of oil deterioration during its work in the engine. This is engine lubricating circuit will be preferably exhibited.

promising part of study to verify in future measurements.

\section{Acknowledgements}

This paper was partially supported by the Gdynia Maritime University grants No. 06/BMN/M/2015 and 360/DS/2015. Authors would like to special thanks for Andrzej Młynarczak from Gdynia Maritime University to make available samples of both fresh and used oil Titan Truck Plus $15 \mathrm{~W} 40$.

\section{Bibliography/Literatura}

[1] Baszanowska E., Otremba Z., Spectrofluorimetric characteristics of used lubricating oil, Diagnostyka, Vol. 15, No. 4, pp. 65-71, 2014.

[2] Baszanowska E., Otremba Z., Application of fluorescence to diagnose the exploitive quality of engine lube oil, Logistyka, No. 6, pp. 17691778, 2014.

[3] Baszanowska E., Zielinski O., Otremba Z., Toczek H., Influence of oil-in-water emulsions on fluorescence properties as observed by excitation-emission spectra, J. Europ. Opt. Soc. Rap. Public., Vol. 8, No. 13069, pp. 13069-1 - 1369-5, 2013.

[4] Markova L. V., Myshkin N.K., Ossia C.V., Kong H., Fluorescence Sensor for Characterization of Hydraulic Oil Degradation, Tribology in industry, Vol. 29, No. 1\&2, 2007.

[5] Mignani A.G., Ciaccheri L., Díaz-Herrera N., Mencaglia A.A., Ottevaere H., Thienpont H., Francalanci S., Paccagnini A., Pavone F., Optical fiber spectroscopy for measuring

Baszanowska Emilia Dr. - Adiunkt in the Faculty of Mechanical Engineering at Gdynia Maritime University.

Dr Baszanowka Emilia - adiunkt na Wydziale Mechanicznym Akademii Morskiej w Gdyni. quality indicators of lubricant oils, Proc. of SPIE, Vol. 7004, pp. 70045R-1 - 70045R-1-4, 2008.

[6] Młynarczak A., Investigation of the influence of aftermarket additive on lubricating properties of Titan Truck Plus 15W40 oil used in marine diesel engines, Zeszyty Naukowe Akademii Morskiej w Gdyni, Nr 76, pp. 62-68, 2012, (in Polish).

[7] Omrani H., Dudelzak A. E., Hollebone B. P., Loock Hans-Peter, Assessment of the oxidative stability of lubricant oil using fiber-coupled fluorescence excitation-emission matrix spectroscopy, Analytica Chimica Acta, 811, pp. 1$12,2014$.

[8] Stelmaszewski A., Fluorescence method for determination of oil identity, Opt. App., Vol XXXIV, No. 3, pp. 405-418, 2004.

[9] Wierzcholski K., Miszczak A.: Algorythm for variable pseudoviscosity coefficients under experimental basis, Tribologia, Vol. 44, No.4, pp.125-136, 2013 (in Polish).

\footnotetext{
Zbigniew Otremba - Professor in the Faculty of Mechanical Engineering at Poznań University of Technology.

Dr hab. Zbigniew Otremba - profesor na Wydziale Mechanicznym Akademii Morskiej w Gdyni
} 